\title{
Changes in Body Growth and Growth-Related Genes under Different Photoperiods in Olive Flounder, Paralichthys olivaceus
}

\author{
Byeong-Hoon Kim ${ }^{1}$, Chi-Hoon Lee ${ }^{1,2}$, Song-Hee Choi ${ }^{1}$, and ${ }^{\text {Young-Don Lee }}{ }^{1}$ \\ ${ }^{I}$ Marine Science Institute, Jeju National University, Jeju 63333, Korea \\ ${ }^{2}$ CR Co., Ltd., Jeju 63333, Korea
}

\begin{abstract}
This study examined the effects of different photoperiod conditions on olive flounder (Paralichthys olivaceus), a commercially important species in Korea. Daily variations in the expression of mRNA for the growth-related genes arylalkylamine N-acetyltransferase2 (AANAT2), preprosomatostatin1 (PSS1), and growth hormone (GH) were examined under a $12 \mathrm{~h}$ light:12 h dark photoperiod. All the genes were expressed at higher level during the dark period. Melatonin injections increased the expression of GH, but did not significantly affect the expression of PSS. Under short-day conditions (10 h:14 h), the fish gained more weight than under long-day conditions (14 h:10 h). A long nighttime induced melatonin secretion and increased the expression of GH mRNA, promoting weight gain in this species. Therefore, we thought that the long day condition in raising olive flounder may be effective in inducing body growth.
\end{abstract}

Key words : Photoperiod, Body growth, Growth-related gene, AANAT2, Olive flounder

\section{INTRODUCTION}

The growth of fish is affected by their specific genetics and various environmental factors, including water temperature, light, and nutrition. Light is the key factor that determines many behavior and ecological characteristics of fish and regulates various endocrine systems. The hormone melatonin, mainly secreted from the pineal organ, is highly sensitive to light and generally shows a daily secretion pattern with an increase in secretion during the night time and a decrease during the day time (Sanchez-Vazquez et al., 1997; Masuda et al., 2003; Rahman et al., 2004). Melatonin is synthesized via the activation of the arylalkylamine $\mathrm{N}$-acetyltransferase (AANAT) enzyme. Melatonin secretion is dependent on the activation of AANAT and is involved in various physiological functions, including growth (Taylor et al., 2005; Vera et al., 2006; Falcon et al., 2007; De Pedro et al., 2008; Falcon et al., 2010).

The growth hormone $(\mathrm{GH})$-insulin-like growth factor (IGF) axis is well known to regulate growth in many teleost fish. GH secretion is induced by the stimulation of GHreleasing hormone, secreted in the hypothalamus. Meanwhile, another hypothalamic hormone, somatostatin (SS), acts mainly to inhibit the secretion of GH in the pituitary. Recent studies of teleost fish have established that SS is a main factor in inhibiting the secretion of GH (Rousseau et al., 2001; Very \& Sheridan, 2002; Canosa et al., 2007). In addition, SS and GH are known to participate in various

Manuscript received April 11, 2019, Received in revised form April 25, 2019, Accepted May 2, 2019

${ }^{\dagger}$ Corresponding Author: Young-Don Lee, Marine Science Institute, Jeju National University, Jeju 63333, Korea. Tel: +82-64-782-8922, Fax: +82-64782-8281, E-mail: leemri@jejunu.ac.kr

This is an Open Access article distributed under the terms of the Creative Commons Attribution Non-Commercial License (http:// creative-commons.org/licenses/by-nc/3.0) which permits unrestricted non-commercial use, distribution, and reproduction in any medium, provided the original work is properly cited. 
physiological functions, such as development, metabolism, immune response, and reproduction (Holstein \& Cederberg, 1988; Poppinga et al., 2007; Zhang at al., 2009). SS genes exist in multiple isoforms in vertebrates. SS1 and SS2 are present in all vertebrates, and SS3, SS4 and SS5 are also found in some teleost fish. Furthermore, the SS6 gene has been reported in zebrafish (Liu et al., 2010). Each SS gene is synthesized from the precursor protein preprosomatostatin (PSS), of which various forms have been identified in some teleost fish (Liu et al., 2010).

The olive flounder (Paralichthys olivaceus) is a very commercially valuable fish species in the Korean aquaculture industry. Many studies are being conducted to improve the efficiency of olive flounder breeding and rearing (Cho et al., 2006; Park et al., 2012; Kim et al., 2015). The objective of the study is to explore the optimal photoperiod conditions for rearing olive flounder to understand their effect on the daily rhythms of growth-related genes (preprosomatostatin1, PSS1 and GH) and arylalkylamine Nacetyltransferase2 (AANAT2) mRNA. In addition, we examined how melatonin injections affected the expression of PSS1 and GH mRNA. Finally, we compared the change in body growth under different light conditions, including short-day and long-day conditions.

\section{MATERIALS AND METHODS}

\section{Fish}

Olive flounder were reared under a natural photoperiod and water temperature in an indoor concrete tank with a flow of seawater at the Marine Science Institute, Jeju National University. The fish were fed commercial pellets (Daehan Co., MP3, Busan, Korea) twice a day.

\section{Experimental design}

Fish ( $\mathrm{n}=49$, average body weight (BW) $45.2 \pm 0.7 \mathrm{~g}$, average total length (TL) $17.1 \pm 0.1 \mathrm{~cm}$ ) were acclimatized for 7 days in an indoor tank under a $12 \mathrm{~h}$ light: $12 \mathrm{~h}$ dark pho- toperiod and natural water temperature conditions. Pelleted feed was provided twice a day at 08:00 $\mathrm{h}$ and 17:00 $\mathrm{h}$ for the first 6 days. After this time, fish were removed and tissue was sampled at $4 \mathrm{~h}$ intervals for 1 day at clock times $6,10,14,18,22$, and $2 \mathrm{~h}$. Before sampling, the fish were anesthetized using MS-222 and decapitated. The brain and pituitary tissues were collected and immediately stored at $80^{\circ} \mathrm{C}$ until analysis.

To determine the effect of melatonin on the expression of PSS1 and GH mRNA, fish were given an intraperitoneal injection (i.p.) of melatonin. Fish $(\mathrm{n}=12$, average $\mathrm{BW}$ $153.1 \pm 3.4 \mathrm{~g}$, average TL $24.7 \pm 0.2 \mathrm{~cm}$ ) were separated into two groups and each group was reared for 3 days under 12 $\mathrm{h}: 12 \mathrm{~h}$ conditions. After this time, the treatment group was injected with melatonin (Sigma, MO, USA) at $1 \mathrm{mg} / \mathrm{kg}$. BW using i.p. at 12:00. Sham group individuals were injected with saline $(0.6 \%$ of $\mathrm{NaCl})$ using i.p. at the same time. At $1 \mathrm{~h}$ after i.p., fish were anesthetized using the MS222 and the brain and pituitary were extracted and stored at $-80^{\circ} \mathrm{C}$ until analysis.

Fish ( $\mathrm{n}=150$, average BW 605.5 \pm 7.0 g, average TL $39.6 \pm 0.1 \mathrm{~cm}$ ) were reared in an indoor tank with a flow of seawater under two different artificial photoperiod conditions, short day (SD, 10 h:14 h) and long day (LD, 14 h:10 h), for 16 weeks. Pelleted feed was supplied twice a day, at 08:00 $\mathrm{h}$ and 17:00 h, until the end of the experiment. During the experiment, the $\mathrm{BW}$ and TL of the fish were measured at 4 weeks intervals.

\section{Gene cloning and sequence analysis}

To perform PSS1 gene cloning in olive flounder, a degenerated primer set was designed on the basis of regions of high identity from PSS1 nucleotide sequences of other fish (GenBank accession numbers: Carassius auratus, CAU40754; Ctenopharyngodon idella, EU571475; Megalobrama pellegrini, AY247267). The olive flounder PSS1 cDNA was amplified by RT-PCR using a degenerate primer set (Table 1). PCR products were identified by elec- 
Table 1. Primer sets used in sequencing, RT-PCR and real time-quantitative PCR

\begin{tabular}{|c|c|c|}
\hline $\begin{array}{c}\text { Primer } \\
\text { sets }\end{array}$ & Genes & Sequence $\left(5^{\prime}-3^{\prime}\right)$ \\
\hline \multirow{2}{*}{$\begin{array}{l}\text { Degen- } \\
\text { erated } \\
\text { primer }\end{array}$} & PSS1-F & GCSCAGAGAGACTCCAAACT \\
\hline & PSS1-R & GAAGTTCTTGCAKCCAGCTT \\
\hline \multirow{6}{*}{$\begin{array}{l}\text { RT- } \\
\text { PCR }\end{array}$} & PSS1-F & CAACAAACAGGAACTGTCTCG \\
\hline & PSS1-R & TTCTTGCATCCAGCTTTCCT \\
\hline & GH-F & TGTCCTCTCAGCCAATCACA \\
\hline & GH-R & GAGAATCCACCTGCTCCATC \\
\hline & Ef1- $\alpha-F$ & GCAGCTCATTGTTGGAGTCA \\
\hline & Ef1- $\alpha-R$ & ACACTTGCAGGGTTGTAGCC \\
\hline \multirow{6}{*}{$\begin{array}{l}\text { Real- } \\
\text { time } \\
\text { qPCR }\end{array}$} & PSS1-F & CAACAAACAGGAACTGTCTCG \\
\hline & PSS1-R & AGGGAAGTTCTCСТССТССА \\
\hline & GH-F & TGAGGACCCAGGTTACATCC \\
\hline & GH-R & GAGAATCCACCTGCTCCATC \\
\hline & Ef1- $\alpha-F$ & GCAGCTCATTGTTGGAGTCA \\
\hline & Ef1- $\alpha-R$ & ACACTTGCAGGGTTGTAGCC \\
\hline
\end{tabular}

PSS1, preprosomatostatin1; GH, growth hormone; EF1- $\alpha$, elongation factor 1-alpha.

trophoresis on a 1\% agarose gel followed by ethidium bromide staining and UV transillumination. The desired size band of PCR products was purified using a DNA purification kit (Promega, Madison WI, USA). Purified DNA fragments were cloned into the pGEM-T Easy Vector System (Promega) and transformed. Plasmid DNA was extracted according to the manufacturer's instructions for the Wizard $^{\circledR}$ SV 96 Plasmid DNA Purification System (Promega, Madison, WI, USA). Extracted plasmid DNA was sequenced using a high-throughput DNA analysis system (Genotech, Korea). Fragment sequences of olive flounder PSS1 were confirmed by BLAST analysis. PSS1 full-length cDNA was obtained by RACE using the SMART RACE cDNA amplification kit (Clontech, Palo Alto, CA, USA) according to the manufacturer's instructions. The obtained cDNA was identified by electrophoresis of ethidium bromide on a $1 \%$ agarose gel, cloned with a T-blunt vector (Solgent, Daejeon, Korea), and sequenced (Genotech, Korea).

Analysis of nucleotide sequences was performed using BLASTN (National Center for Biotechnology Information, National Institutes of Health, Bethesda, MD, USA). The signal peptides were identified with SignalP3.0 (www.cbs. dtu.dk/services/SignalP). Multiple alignment of amino acid sequences was analyzed using the ClustalW software (www.ebi.ac.uk/clustalw/). A phylogenetic tree was constructed by PHYLIP package (ver. 3.63, J. Felsenstein, University of Washington, Seattle, WA, USA).

\section{Tissue-specific expression of PSS1 mRNA}

For tissue-specific expression analysis of PSS1 mRNA, brain tissue was divided into five portions: telencephalon, optic tectum, diencephalon, cerebellum, and medulla oblongata. Further pituitary and other peripheral tissues (heart, kidney, liver, intestine, spleen, gonad, and muscle) were also analyzed. PSS1 mRNA expression was confirmed using the RT-PCR and real-time quantitative PCR (real-time qPCR) analysis.

\section{Total RNA extraction and cDNA synthesis}

For extraction of total RNA, brain and pituitary tissues were absolutely homogenized with RNAiso Plus (Takara Bio Inc, Otsu, Japan) reagent. Total RNA was extracted following the manufacturer's protocol and total RNA concentration were measured using the Nano Vue (GE Healthcare, ver. 1.0.1, UK). Total RNA was treated using the RQ1 RNase-Free DNase (Promega, Madison, WI, USA) and cDNA was synthesized using $500 \mathrm{ng}$ of total RNA and A260/280 ratio of 1.8-2.0 with the PrimeScript RT reagent kit (Takara Bio Inc. Otsu, Japan). The synthesized cDNA was used in the analysis of PSS1 gene cloning and real-time qPCR. 


\section{RT-PCR and real-time $\mathrm{QPCR}$}

For RT-PCR and real-time qPCR, PSS1 primers were designed using the isolated PSS1 gene nucleotide sequence in olive flounder. GH primers were designed using information from the NCBI web-site (Table 1). The RT-PCR conditions consisted of a denaturation cycle of $94^{\circ} \mathrm{C}$ for $2 \mathrm{~min}$, followed by 35 PCR cycles each consisting of $45 \mathrm{~s}$ denaturation at $94^{\circ} \mathrm{C}, 45 \mathrm{~s}$ annealing at $55^{\circ} \mathrm{C}$, and $1 \mathrm{~min}$ extension at $72^{\circ} \mathrm{C}$. Extension time in the last cycle was elongated to $3 \mathrm{~min}$. The obtained PCR products were electrophoresed with ethidium bromide on $2 \%$ agarose gel and visualized on a UV transilluminator. Negative controls were examined for each primer whenever cDNA was excluded from the RT-PCR.

Real-time qPCR was performed using the $\mathrm{CFX}^{\mathrm{TM}}$ Realtime System (Bio-Rad, Hercules, CA, USA) with Evagreen premix PCR kit (ABM Inc. Canada). Real-time qPCR amplification was performed by initial denaturation at $95^{\circ} \mathrm{C}$ for $10 \mathrm{~min}, 40$ cycles of $95^{\circ} \mathrm{C}$ for $15 \mathrm{~s}, 60^{\circ} \mathrm{C}$ for $1 \mathrm{~min}$, and $60^{\circ} \mathrm{C}$ for $1 \mathrm{~min}$. The EF1- $\alpha$ (elongation factor 1-alpha) gene was used as a reference gene.

\section{Statistical analysis}

All gene expression data from real-time qPCR were expressed as mean $\pm \mathrm{SE}$ (SEM). All statistical differences among means were analyzed by one-way analysis of variance (ANOVA) followed by Duncan's multiple range test and independent sample $t$-tests using Statistics 21.0 for Windows (SPSS Inc.).

\section{RESULTS}

1. Isolation of olive flounder PSS1 cDNA and phylogenetic analysis

We isolated the PSS1 full sequence information from the brain tissue and registered a PSS1 sequence with NCBI (accession number AB693833). The PSS1 sequence totaled $638 \mathrm{bp}$ fragments and consisted of a 96-bp 5'-untranslated region (UTR), a 363-bp open reading frame (ORF), and a 179-bp 3'-UTR (Fig. 1). In addition, a signal peptide consisting of 26 amino acids was identified and 14 SS-14-1 amino acids were identified in C-terminal (Fig. 1). In addi-

1 ACGCGGGGAGAACATCCAGAGACACGCAGACTGAGACAGCCAGAGACAGAGAGACAGACA

61 GTTAGACAGTGAGAGACAGACTCAGACAGACAGGTGATGAAGATGGTGTCCTCCTCGCGC

$$
\begin{array}{llllllll}
\mathbf{M} & \mathrm{K} & \mathbf{M} & \mathrm{V} & \mathbf{S} & \mathbf{S} & \mathbf{S} & \mathbf{R}
\end{array}
$$

121 TGCCTCCTCCTCCTCTTCCTCTCTCTCAGCGCCTCCATCAGCTGCTGCTCCGCCGCTCAG $\begin{array}{llllllllllllllllllll}\text { C } & \text { L } & \text { L } & \text { L } & \text { L } & \text { F } & \text { L } & \text { S } & \text { L } & \text { S } & \text { A } & \text { S } & \text { I } & \text { S } & \text { C } & \text { C } & \text { S } & \text { A } & \text { A } & \text { Q }\end{array}$

181 AGAGACTCCAAACTCCGCCTGTTGCTGCACAGGAGCCCGCTGCTCTCCAACAAACAGGAA $\begin{array}{llllllllllllllllllll}R & D & S & K & L & R & L & L & L & H & R & S & P & L & L & S & N & K & Q & E\end{array}$

241 CTGTCTCGCTCCTCGCTGGCCGAGCTGCTCCTGTCCGACCTCCTGCAGGTGGAGAACGAG $\begin{array}{llllllllllllllllllll}L & S & R & S & S & L & A & E & L & L & L & S & D & L & L & Q & V & E & N & E\end{array}$

301 GCTCTGGAGGAGGAGAACTTCCCTCTGGCTGACGGAGAACCTGAGGACATCCATGTGGAT $\begin{array}{llllllllllllllllllll}A & L & E & E & E & N & F & P & L & A & D & G & E & P & E & D & I & H & V & D\end{array}$

361 CTGGAACGAGCCGCCGGTGCCACGGGGCCGCTGCTCGCCCCCCGAGAGAGGAAAGCAGGC \begin{tabular}{llllllllllllllllllllll}
$L$ & $E$ & $R$ & $A$ & $A$ & $G$ & $A$ & $T$ & $G$ & $P$ & $L$ & $L$ & $A$ & $P$ & $R$ & $E$ & $R$ & $K$ & $A$ & $G$ \\
\hline
\end{tabular}

421 TGCAAGAACTTCTTCTGGAAGACCTTCACTTCCTGCTGAGAGCTCCGCCCCCTCACCTCC $\begin{array}{llllllllllllll}\mathrm{C} & \mathrm{K} & \mathrm{N} & \mathrm{F} & \mathrm{F} & \mathrm{W} & \mathrm{K} & \mathrm{T} & \mathrm{F} & \mathrm{T} & \mathrm{S} & \mathrm{C} & *\end{array}$

481 ATCAGACTCTGTACAGGAACTGATCCGATTGGTTTGGAGGAAAAGTTTAGATTCTTCTGA

541 GCTGATTCTTTCTGAATGTAAAACTTGATGAAAATATTTTTAATGGTTGTTCGAATAAAA

601 TCTGTTTGAGATAAAAAAAAAAAAAAAAAAAAAAAAA

Fig. 1. Nucleotide sequences and deduced amino acid sequences of olive flounder PSS1. The putative signal peptide sequences are shown as bold upper case letters. Polyadenylation signals (AATAAA) in the 3'-UTR are underlined. The amino acid sequences for somatostatin-14 are underlined at the C-terminus of precursor. PSS1, preprosomatostatin1. 


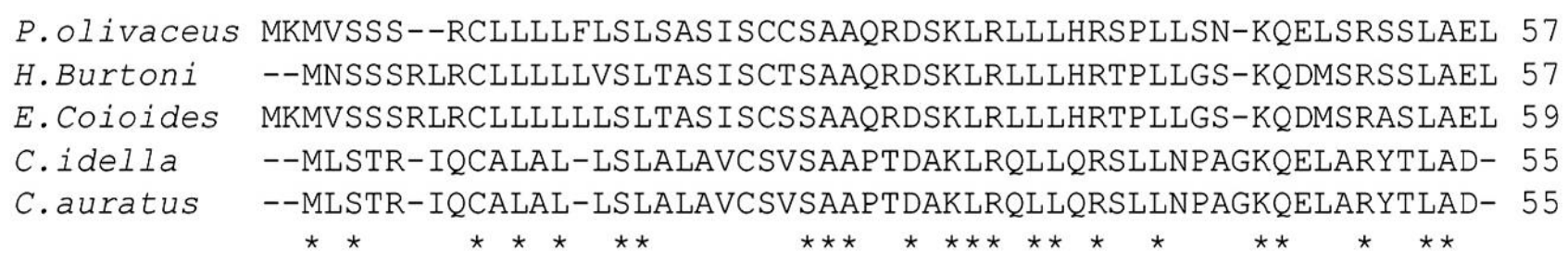

P.olivaceus LLSDLLQVENEALEEENFPLADGEPEDIHVDLER-AAGATGPLLAPRERKAGCKNFFWKT 116

H.burtoni LLSDLLQVENEALEEENFPLADGEPEDIRVDLER--AAGSGPLLAPRERKAGCKNFFWKT 115

E.Coioides LLSDLLQVENEALEEENFPLAEGEPEDVHVDLERAAAAGSGPLLAPRERKAGCKNFFWKT 119

C.idella LLSDLVQAENEALEPEDLSRA-VEKDDVRLELER----AAGPMLAPRERKAGCKNFFWKT 110

C.auratus LLSELVQAENEALEPEDLSRA-VEKDEVRLELER----AAGPMLAPRERKAGCKNFFWKT 110

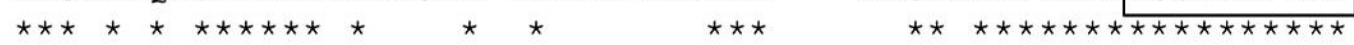

\begin{tabular}{l|l|l} 
P.olivaceus & FTSC & 120 \\
H.burtoni & FTSC & 119 \\
E. Coioides & FTSC & 123 \\
C.idella & FTSC & 114 \\
C. auratus & FTSC & 114 \\
& &
\end{tabular}

Fig. 2. Comparison of deduced amino acid sequences with olive flounder PSS1 and other fish species. The amino acid sequences for somatostatin-14 was boxed. Identical amino acids are indicated by an asterisk. PSS1, preprosomatostatin1.

tion, the results of multiple alignment between olive flounder PSS1 cDNA and PSS1 cDNA in other fish all matched the 14 amino acids of SS-14-1 (Fig. 2).

The identity analysis results between olive flounder PSS1 and PSS1 from other fish showed $45 \%$ to $86 \%$ agreement (Table 2).

Phylogenetic analysis revealed that the olive flounder PSSI was grouped with Haplochromis burtoni (Fig. 3).

\section{Tissue-specific distribution and relative expression}

We observed the tissue distribution and relative expression of PSS1 mRNA using RT-PCR and real-time qPCR (Fig. 4). The RT-PCR analysis showed that, the expression band of PSS1 mRNA was detected in the telencephalon, optic tectum, diencephalon, and medulla oblongata of the brain. Among the peripheral tissues, weak expression of PSS1 mRNA was detected in the gonads (Fig. 4A). Real-time qPCR analysis revealed that the highest level of expression of PSS1 mRNA was detected in the telencephalon. PSS1 mRNA expression was
Table 2. Overall amino acid identities of PSS1 between olive flounder and other fishes

\begin{tabular}{llc}
\hline \hline & Species & $\begin{array}{c}\text { Homology } \\
(\%)\end{array}$ \\
\hline Teleostei & Haplochromis burtoni & 86.0 \\
Perciformes & Epinephelus coioides & 85.0 \\
& Siniperca chuatsi & 85.0 \\
Cypriniformes & Ctenopharyngodon idella & 54.0 \\
& Megalobrama pellegrini & 53.0 \\
& Danio rerio & 53.0 \\
& Carassius auratus & 52.0 \\
Lepidosireniformes & Protopterus annectens & 42.0 \\
& Pelteobagrus vachellii & 41.0 \\
Chondrostei & & \\
Acipenseriformes & Acipenser sinensis & 45.0 \\
\hline
\end{tabular}

PSS1, preprosomatostatin1. 


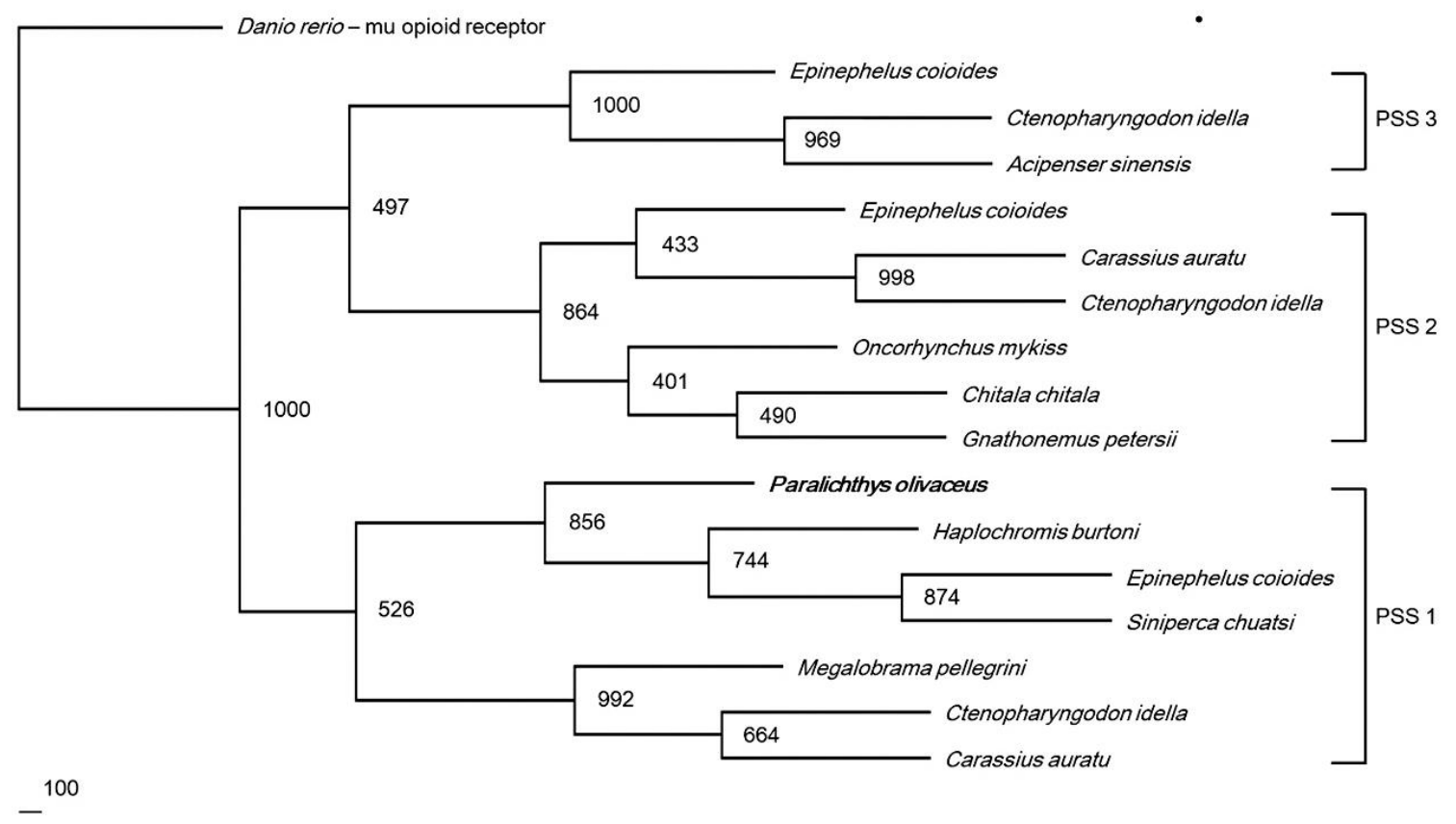

Fig. 3. Phylogenetic tree of PSS1 between olive flounder and other fishes. PSS1, preprosomatostatin1.

also detected in the diencephalon, optic tectum, and medulla oblongata (Fig. 4B).

\section{Daily variations in expression of AANAT2, PSS1} and $\mathrm{GH}$ mRNA

We investigated the daily variations of AANAT2, PSS1 and GH mRNA expression in the brain and pituitary under $12 \mathrm{~h}: 12 \mathrm{~h}$ conditions, and the mRNA expression of all genes was higher at night-time than during the day (Fig. 5). The expression of AANAT2 and PSS1 mRNA in the brain continued at low levels from CT6 to CT14, but, the expression was highest at CT22 (Figs. 5A and 5B). The expression of GH mRNA in the pituitary remained steady at low levels from CT6 to CT22 and rapidly increased at CT2 (Fig. 5C).

\section{Effect of melatonin on the expression of PSS1} and $\mathrm{GH}$ mRNA

The effects of melatonin injection on the expression of PSS1 and GH mRNA in the brain and pituitary, respectively, shown in Fig. 6. The PSS1 mRNA expression in the brain did not differ between the treatment and sham groups
A

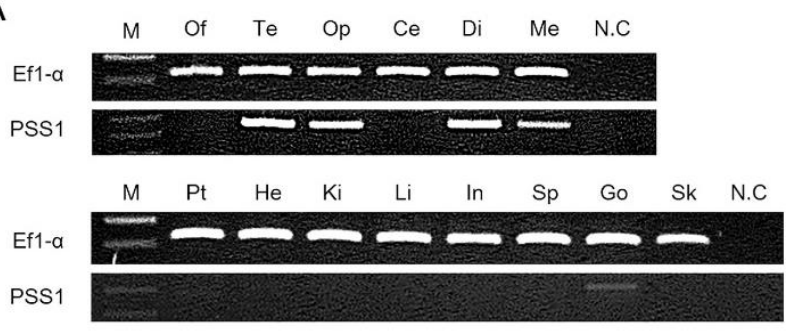

B

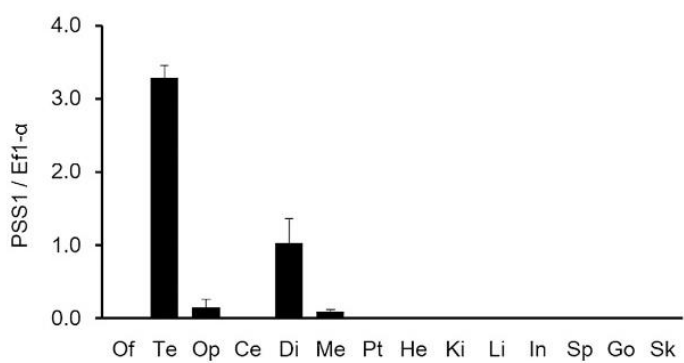

Fig. 4. Tissue specific expression of PSS1 mRNA in olive flounder by RT-PCR (A) and real time-quantitative PCR. M, 100 bp DNA ladder marker; of, olfactory lob; Te, telencephalon; Op, Optic tectum; hy, hypothalamus; $\mathrm{Ce}$, cerebellum; $\mathrm{Me}$, medulla oblongata; Pt, pituitary; He, heart; Ki, kidney; L, liver; In, intestine; Sp, spleen; Go, gonad; Sk, skin; N.C, negative control. The EF1- $\alpha$ (elongation factor 1alpha) gene was used as an reference gene. PSS1, preprosomatostatin1. 

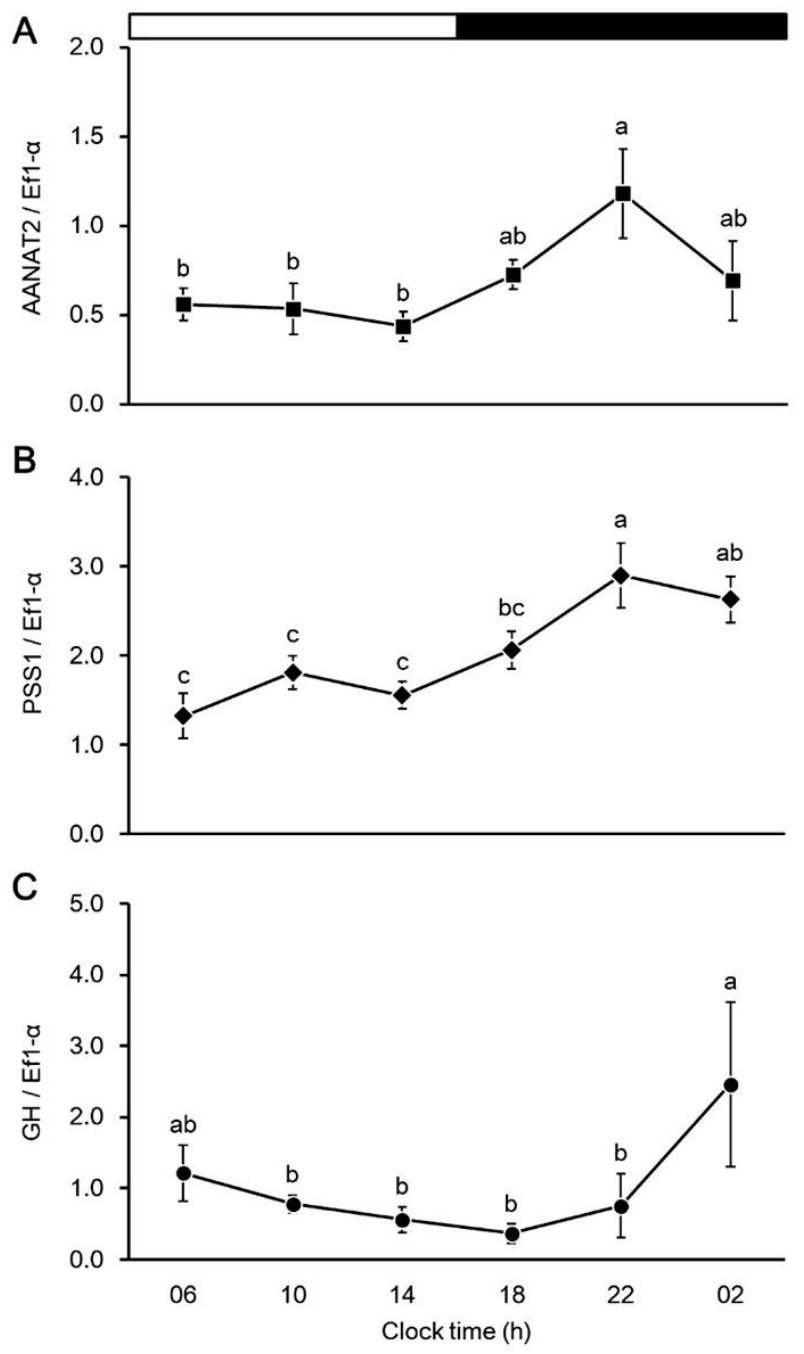

Fig. 5. Daily variations of AANAT2 (A), PSS1 (B) and GH (C) mRNA expression under 12L:12D photoperiod condition from olive flounder. The different letters indicate statistically different values $(p<0.05)$. Values are mean \pm SEM. AANAT2, acetyltransferase2; PSS1, preprosomatostatin1; GH, growth hormone.

(Fig. 6A). However, the GH mRNA expression in the pituitary was significantly higher in the treatment group than in the sham group (Fig. 6B).

5. Changes in body growth under different photoperiodic conditions

The fish were reared for 16 weeks under SD and LD conditions, and the changes in body growth during this
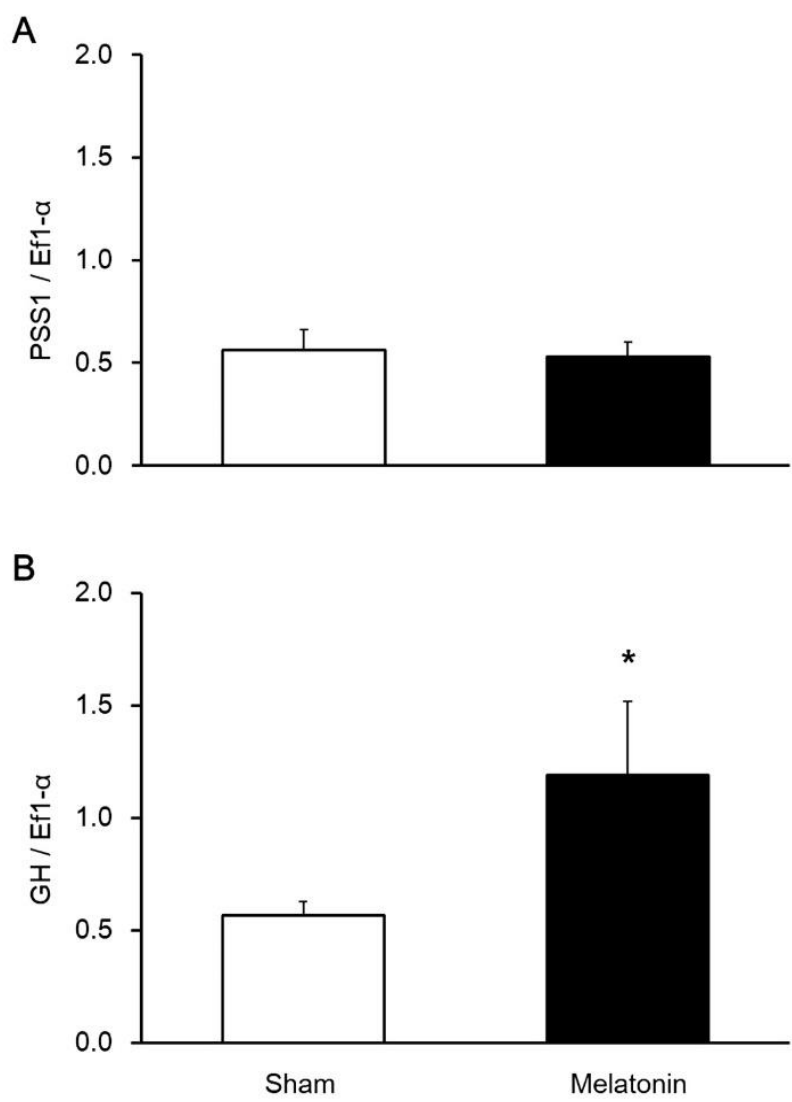

Fig. 6. The PSS1 (A), GH (B) expressions in the olive flounder brain and pituitary, respectively by after 1 hour of melatonin treatment. Asterisk represents statistical difference at $p<0.05$. Values are mean \pm SEM. PSS1, preprosomatostatin1; GH, growth hormone.

period are shown in Fig. 7. The BW showed no significant difference between the two groups until 12 weeks; by 16 weeks, the $\mathrm{BW}$ of the SD group was significantly higher than in the LD group ( $p<0.05$; Fig. 7A).

\section{DISCUSSION}

We investigated the daily variations in AANAT2, PSS1, and GH mRNA expression in the brains and pituitary glands of olive flounder. Variations in melatonin secretion or AANAT mRNA expression have been reported in many teleost fish (Migaud et al., 2006; Nikaido et al., 2009; Falcon et al., 2010; Seth \& Maitra, 2010; Liu et al., 2019). In 

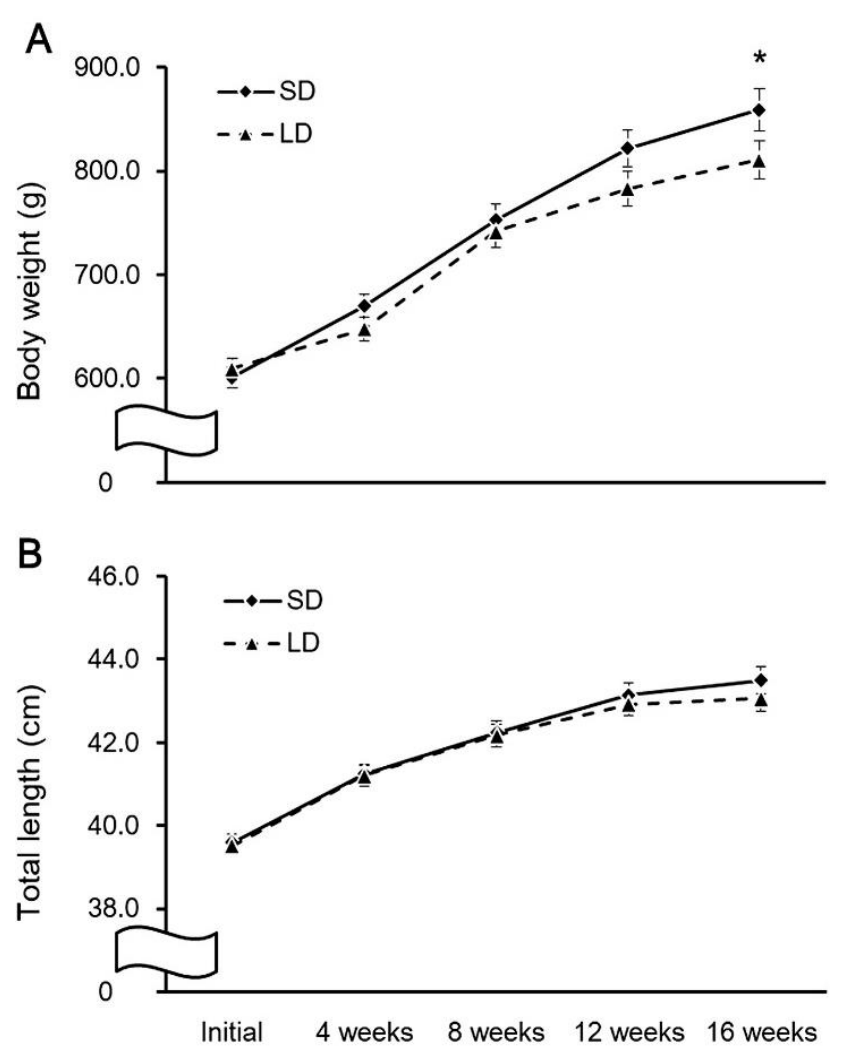

Fig. 7. Changes of body weight (A) and total length (B) in olive flounder under different photoperiod conditions (SD, short day 10L:14D; LD, long day 14L:10D). Asterisk represents statistical difference at $p<0.05$. Values are mean $\pm \mathrm{SEM}$.

a recent study of air-breathing catfish (Clarias gariepinus), AANAT2 mRNA expression followed a circadian rhythm (Singh et al., 2017). In the present study, increased AANAT2 mRNA expression occurred during the dark phase relative to the light phase, and this expression pattern was also found under a continuous dark condition. Although many studies have examined melatonin variation, few have focused on the study of the variation pattern of SS, and only a few have reported that SS levels in plasma are higher at night than during the day in the rats (Peinado et al., 1990; Ishikawa et al., 1997). In one of our previous studies, we studied the variation patterns of melatonin secretion and SS mRNA expression in tiger puffer (Takifugu rubripes), observed that the melatonin secretion and SS1 mRNA expression increased at night relative to its level during the day under a $12 \mathrm{~h}: 12 \mathrm{~h}$ photoperiod (Kim et al., 2017). The variation pattern of GH secretion is known through studies of some teleost fish (Holloway et al., 1994; Gomez et al., 1996). For instance, the daily expression patterns of GH mRNA were observed in rabbitfish (Siganus guttatus) (Ayson \& Takemura, 2006). According to that study, the GH mRNA expression was significantly higher during the dark phase than during the light phase under $12 \mathrm{~h}: 12 \mathrm{~h}$ photoperiod. However, this expression pattern disappeared under continuous light and continuous darkness, and these results suggested that the expression of GH mRNA is regulated according to the light and dark cycle. In the present study, the variations in the expression of AANAT2, PSS1, and GH mRNA in olive flounder was similar to that observed in studies on other fish. Therefore, expression of AANAT2, PSS1, and GH mRNA in olive flounder follow a nocturnal rhythm. Our study did not determine whether this nocturnal rhythm was caused by the presence/absence of light or by a circadian rhythm unrelated to light, so we recommend further study of the circadian rhythm.

We investigated the effect of melatonin on the expression of PSS1 and GH mRNA to explore the correlation between melatonin and PSS1 and GH genes. Few previous studies have examined the relationship between melatonin and PSS1 and the only species used in such studies were rat and tiger puffer. Examination of the hippocampus of rats showed that melatonin treatment caused a decline in somatostatin-like immunoreactivity, as well as in the number of SS receptors, but chronic treatment with melatonin did not result in SS inhibition (Izquierdo-Claros et al., 2004). In tiger puffer, melatonin treatment did not change the expression of SS mRNA in the brain (Kim et al., 2017). In the present study, melatonin treatment by i.p. did not results in activation of PSS1 mRNA expression in the brain, a result that was similar to that found in tiger puffer. Thus, we suggest that melatonin probably does not directly affect the expression of SS mRNA in the brain of olive 
flounder.

However, the expression of GH mRNA in the pituitary did increase after melatonin treatment. Melatonin is a major factor with various physiological effects in fish, but few studies have examined the effects of melatonin on $\mathrm{GH}$ secretion in the pituitary glands of fish. An in vivo experiment with rainbow trout (Oncorhynchus mykiss) observed that GH secretion in the pituitary increased after melatonin treatment in cultured trout, but also observed that GH secretion was inhibited under specific pharmacological conditions (Falcon et al., 2003). The author concluded that melatonin may have a bimodal effect that either induces or inhibits GH secretion in the pituitary. Our experimental result suggested that, melatonin affects the activation of $\mathrm{GH}$ mRNA in olive flounder. Nocturnal variation in $\mathrm{GH}$ mRNA expression in the pituitary appears to be synchronized and is affected by the nocturnal variation of AANAT2 mRNA expression in the brain, whereas the nocturnal variation of PSS1 mRNA expression in the brain appears to have its own variation pattern, independent of AANAT2 mRNA expression.

Photoperiod is a very important environmental factor affecting the physiology of fish, especially their growth and reproduction. Most studies of the effect of photoperiod on growth in various fish species reported that a LD condition enhanced the growth of fish (El-Sayed \& Kawanna, 2004; Gines et al., 2004; Carrillo et al., 2010; Kitagawa et al., 2015). For example, red sea bream (Pagrus major) that were reared under various photoperiod conditions $(6 \mathrm{~h}: 6 \mathrm{~h}$, $12 \mathrm{~h}: 12 \mathrm{~h}, 16 \mathrm{~h}: 8 \mathrm{~h}$, and $24 \mathrm{~h}: 0 \mathrm{~h})$ showed enhanced growth performance under $16 \mathrm{~h}: 8 \mathrm{~h}$ and $24 \mathrm{~h}: 0 \mathrm{~h}$ photoperiods and improved food intake, feed efficiency, and digestibility compared to other photoperiod conditions (Biswas et al., 2005). Blunt snout bream (Megalobrama amblycephala) that were reared under different photoperiod conditions ( 8 h:16 h, 12 h:12 h, and 16 h:8 h) showed significantly enhanced growth performance under a long photoperiod, as well as increased expression of GH and IGF-1
mRNA in the brain and liver, respectively (Tian et al., 2019).

However, our findings conflict with these results. In the present study, the olive flounder gained more weight under the SD condition than the LD condition. Interspecies differences in fish may be due to different feeding states, growth stages and, photoperiod conditions in various experiments. In European sea bass (Dicentrarchus labrax), plasma melatonin levels were affected by different photoperiods, and the duration of high secretion of melatonin at night was increased when night time was extended, suggesting that the melatonin secretion is regulated by photoperiod (Bayarri et al., 2004). Thus, in the present study, the SD condition that induced weight gain in olive flounder was probably a result of prolonged high melatonin secretion and GH mRNA expression due to extended night time. However, this hypothesis is difficult to prove without additional data, and further study is needed of the characteristics of melatonin secretion and GH mRNA expression due to photoperiod change.

In conclusion, we investigated the hypothesis that melatonin produced at night regulates the expression of growthrelated genes (PSS1 and GH) and affects the body growth of olive flounder. As a result, the expression of AANAT2, PSS1, and GH mRNA showed nocturnal variations, and melatonin injection was able to induce higher expression of GH mRNA in the pituitary. Olive flounder gained more weight under the SD condition than under the LD condition. Therefore, we recommend that aquaculture facilities rearing olive flounder use a photoperiod with a long nighttime to improve body growth, but the mechanism underpinning the effects of melatonin on growth-related genes remains unclear. The present study provides basic data on environmental conditions for efficient aquaculture practices.

\section{ACKNOWLEDGEMENTS}

This research was supported by the 2018 scientific promotion program funded by Jeju National University. 


\section{REFERENCES}

Ayson FG, Takemura A (2006) Daily expression patterns for mRNAs of GH, PRL, SL, IGF-I and IGF-II in juvenile rabbitfish, Siganus guttatus, during 24-h light and dark cycles. Gen Comp Endocrinol 149:261-268.

Bayarri MJ, Rodriguez L, Zanuy S, Madrid JA, SanchezVazquez FJ, Kagawa H, Okuzawa, Carrillo M (2004) Effect of photoperiod manipulation on the daily rhythms of melatonin and reproductive hormones in caged European sea bass (Dicentrarchus labrax). Gen Comp Endocrinol 136:72-81.

Biswas AK, Seoka M, Inoue Y, Takii K, Kumai H (2005) Photoperiod influences the growth, food intake, feed efficiency and digestibility of red sea bream (Pagrus major). Aquaculture 250:666-673.

Canosa LF, Chang JP, Peter RE (2007) Neuroendocrine control of growth hormone in fish. Gen Comp Endocrinol 151:1-26.

Carrillo M, Begtashi I, Rodriguez L, Marin MC, Zanuy S (2010) Long photoperiod on sea cages delays timing of first spermiation and enhances growth in male European sea bass (Dicentrarchus labrax). Aquaculture 299: 157-164.

Cho SH, Lee SM, Park BH, Lee SM (2006). Effect of feeding ratio on growth and body composition of juvenile olive flounder Paralichthys olivaceus fed extruded pellets during the summer season. Aquaculture 251:7884.

De Pedro N, Martinez-Alvarez RM, Delgado MJ (2008) Melatonin reduces body weight in goldfish (Carassius auratus): Effects on metabolic resources and some feeding regulators. J Pineal Res 45:32-39.

El-Sayed AFM, Kawanna M (2004) Effects of photoperiod on the performance of farmed Nile tilapia Oreochromis niloticus: I. Growth, feed utilization efficiency and survival of fry and fingerlings. Aquaculture 231:393402.
Falcon J, Besseau L, Fazzari D, Attia J, Gaildrat P, Beauchaud M, Boeuf G (2003) Melatonin modulates secretion of growth hormone and prolactin by trout pituitary glands and cells in culture. Endocrinology 144:4648-4658.

Falcon J, Besseau L, Sauzet S, Boeuf G (2007) Melatonin effects on the hypothalamo-pituitary axis in fish. Trends Endocrinol Metab 18:81-88.

Falcon J, Migaud H, Munoz-Cueto JA, Carrillo M (2010) Current knowledge on the melatonin system in teleost fish. Gen Comp Endocrinol 165:469-482.

Gines R, Afonso JM, Arguello A, Zamorano MJ, Lopez JL (2004) The effects of long-day photoperiod on growth, body composition and skin colour in immature gilthead sea bream (Sparus aurata L.). Aquac Res 35:12071212.

Gomez JM, Boujard T, Fostier A, Le Bail PY (1996). Characterization of growth hormone nycthemeral plasma profiles in catheterized rainbow trout (Oncorhynchus mykiss). J Exp Zool 274:171-180.

Holloway AC, Reddy PK, Sheridan MA, Leatherland JF (1994). Diurnal rhythms of plasma growth hormone, somatostatin, thyroid hormones, cortisol and glucose concentrations in rainbow trout, Oncorhynchus mykiss, during progressive food deprivation. Biol Rhythm Res 25:415-432.

Holstein B, Cederberg C (1988) Effect of somatostatin on basal and stimulated gastric secretion in the cod, Gadus morhua. Am J Physiol 254:183-188.

Ishikawa M, Mizobuchi M, Takahashi H, Bando H, Saito S (1997) Somatostatin release as measured by in vivo microdialysis: Circadian variation and effect of prolonged food deprivation. Brain Res 749:226-231.

Izquierdo-Claros RM, Boyano-Adanez MDC, ArillaFerreiro E (2004) Acutely administered melatonin decreases somatostatin-binding sites and the inhibitory effect of somatostatin on adenylyl cyclase activity in the rat hippocampus. J pineal Res 36:87-94.

Kim BH, Hur SP, Hur SW, Takeuchi Y, Takemura A, Lee 
YD (2017) Circadian rhythm of melatonin secretion and growth-related gene expression in the tiger puffer Takifugu rubripes. Fish Aquat Sci 20:17.

Kim HC, Lee CH, Hur SP, Kim BH, Park JY, Lee YD (2015). Possible involvement of photoperiodic regulation in reproductive endocrine system of female olive flounder Paralichthys olivaceus. Dev Reprod 19:11-17. Kitagawa AT, Costa LS, Paulino RR, Luz RK, Rosa PV, Guerra-Santos B, Fortes-Silva R (2015) Feeding behavior and the effect of photoperiod on the performance and hematological parameters of the Pacama catfish (Lophiosilurus alexandri). Appl Anim Behav Sci 171:211-218.

Liu Y, Lu D, Zhang Y, Li S, Liu X, Lin H (2010) The evolution of somatostatin in vertebrates. Gene 463:21-28.

Liu Q, Manning AJ, Duston J (2019) Light intensity and suppression of nocturnal plasma melatonin in Arctic charr (Salvelinus alpinus). Comp Biochem Physiol A Mol Integr Physiol 228:103-106.

Masuda T, Iigo M, Mizusawa K, Naruse M, Oishi T, Aida K, Tabata M (2003) Variations in plasma melatonin levels of the rainbow trout (Oncorhynchus mykiss) under various light and temperature conditions. Zoolog Sci 20:1011-1016.

Migaud H, Taylor JF, Taranger GL, Davie A, CerdaReverter JM, Carrillo M, Hansen T, Bromage NR (2006) A comparative ex vivo and in vivo study of day and night perception in teleosts species using the melatonin rhythm. J Pineal Res 41:42-52.

Nikaido Y, Ueda S, Takemura A (2009) Photic and circadian regulation of melatonin production in the Mozambique tilapia Oreochromis mossambicus. Comp Biochem Physiol A Mol Integr Physiol 152:77-82.

Park JW, Lee YM, Noh JK, Kim HC, Park CJ, Hwang IJ, Kim SY, Lee JH (2012) The morphological study of wild and farmed olive flounder (Paralichthys olivaceus): The role of indirect selection within and between populations. Dev Reprod 16:309-314.
Peinado MA, Fajardo N, Hernandez G, Puig-Domingo M, Viader M, Reiter RJ, Webb SM (1990) Immunoreactive somatostatin diurnal rhythms in rat pineal, retina and harderian gland: Effects of sex, season, continuous darkness and estrous cycle. J Neural Transm Gen Sect 81:63-72.

Poppinga J, Kittilson JK, McCormick SD, Sheridan MA (2007) Effects of somatostatin on the growth hormoneinsulin-like growth factor axis and seawater adaptation of rainbow trout (Oncorhynchus mykiss). Aquaculture 273:312-319.

Rahman MS, Kim BH, Takemura A, Park CB, Lee YD (2004) Effects of moonlight exposure on plasma melatonin rhythms in the seagrass rabbitfish, Siganus canaliculatus. J Biol Rhythm 19:325-334.

Rousseau K, Le Belle N, Pichavant K, Marchelidon J, Chow BK, Boeuf G, Dufour S (2001) Pituitary growth hormone secretion in the turbot, a phylogenetically recent teleost, is regulated by a species-specific pattern of neuropeptides. Neuroendocrinology 74:375-385.

Sanchez-Vazquez FJ, Iigo M, Madrid JA, Zamora S, Tabata M (1997) Daily cycles in plasma and ocular melatonin in demand-fed sea bass, Dicentrarchus labrax L. J Comp Physiol B 167:409-415.

Seth M, Maitra SK (2010) Importance of light in temporal organization of photoreceptor proteins and melatoninproducing system in the pineal of carp Catla catla. Chronobiol Int 27:463-486.

Singh KM, Saha S, Gupta BBP (2017) Season-dependent effects of photoperiod and temperature on circadian rhythm of arylalkylamine $\mathrm{N}$-acetyltransferase 2 gene expression in pineal organ of an air-breathing catfish, Clarias gariepinus. J Photoch Photobio B 173:140-149.

Taylor JF, Migaud H, Porter MJ, Bromage NR (2005) Photoperiod influences growth rate and plasma insulin-like growth factor-I levels in juvenile rainbow trout, $\mathrm{On-}$ corhynchus mykiss. Gen Comp Endocrinol 142:169-185.

Tian H, Zhang D, Li X, Jiang G, Liu W (2019) Photoperi- 
od affects blunt snout bream (Megalobrama amblycephala) growth, diel rhythm of cortisol, activities of antioxidant enzymes and mRNA expression of GH/IGF-

I. Comp Biochem Physiol B Biochem Mol Biol 233:410.

Very NM, Sheridan MA (2002) The role of somatostatins in the regulation of growth in fish. Fish Physiol Biochem. 27:217-226.

Vera LM, Madrid JA, Sanchez-Vazquez FJ (2006) Loco- motor, feeding and melatonin daily rhythms in sharpsnout seabream (Diplodus puntazzo). Physiol Behav 88:167-172.

Zhang L, Li W, Hong X, Lin H (2009) Regulation of preprosomatostatin 1 (PSS1) gene expression by $17 \beta-$ estradiol and identification of the PSS1 promoter region in orange-spotted grouper (Epinephelus coioides). Mol Cell Endocrinol 311:87-93. 